Research

\title{
Modified sodium molybdate as an efficient high yielding heterogeneous catalyst for biodiesel from Ghanaian indigenous Camelina sativa as a non-edible resource
}

\author{
Mohammed Takase $^{1} \cdot$ Paul Kwame Essandoh ${ }^{1} \cdot$ Rogers Kipkoech $^{1}$
}

Received: 17 October 2020 / Accepted: 26 November 2020

(c) The Author(s) 2021 OPEN

\begin{abstract}
Sodium molybdate $\left(\mathrm{Na}_{2} \mathrm{MoO}_{4}\right)$ has been synthesized and investigated as a heterogeneous solid catalyst for biodiesel from Camelina sativa seed oil. Transesterification reactions occurred under atmospheric conditions with relatively, low temperature short reaction time and normal pressure. The prepared catalyst was characterised by means of SEM, TGA, UV, $\mathrm{XRD}$ and FTIR. The properties of the biodiesel were compared with international standards. The transesterification reaction was very efficient with the optimum yield higher than $95 \%$ at methanol to oil molar ratio of 17:1, catalyst amount of $6 \%$, reaction temperature of $60^{\circ} \mathrm{C}$ and reaction time of $2.5 \mathrm{~h}$. The molybdate complex had a high Lewis acidity and most certainly act as alcohol O-H bond leading to a transient species which has high nucleophilic character. The catalyst was easily recovered and after being washed for three times, showed capacity of recyclability for another catalytic reaction of five cycles with similar activity. The properties of the biodiesel were comparable to international standards.
\end{abstract}

Keywords Transesterification · Methanolysis · Heterogeneous catalysis · Sodium molybdate · Biodiesel

\section{Introduction}

Continuous reduction in petroleum fuel, concerns over global warming and climate change coupled with environmental pollution caused by burning of conventional fuels has generated interest for biodiesel as alternative fuels [1]. Principally, biodiesel is produced by transesterification reaction using oil and alcohol in the present of a catalysts [2]. It is renewable, biodegradable, has low emission profiles, high flash point and environmentally friendly $[2,3]$. The application of heterogeneous catalysts in biodiesel production is highly recommended as a result of its high catalytic efficiency and mild reaction conditions [4]. Heterogenous catalysts can potentially reduce the expenses involved in producing biodiesel through elimination of the excess alcohol as well as many other downstream processing steps [5]. Presently, the most common heterogeneous catalysts used for the production of biodiesel include oxides of metals [6,7], metal complexes [8], active metals loaded on supports [9], resins [10, 11], lipases [12] zeolites [13] etc. Majority of these catalysts exist in powder form and thus making separation hard [14].

Transitional metals which composed of various acids and bases are now commonly used. Typical examples of those transitional metals commonly used include in biodiesel production include $\mathrm{MnO}, \mathrm{ZnO}$, TiO, WO and ZrO [15]. Amongst the transitional metals, Lanthanum contains complexes that produces many doles with high surface area, small crystal size and high number of basic sites [16]. The metal composition and acidity or basicity of the supported catalysts plays a critical role in the catalyst activity [17]. $\mathrm{ZnO}-\mathrm{Al}_{2} \mathrm{O}_{3}-\mathrm{La}_{2} \mathrm{O}_{3}[18], \mathrm{CaO}^{-\mathrm{La}_{2} \mathrm{O}_{3}}$ [19], $\mathrm{La}-\mathrm{CaO}, \mathrm{La} / \mathrm{Mn},[16]$ have however, all been

$\triangle$ Mohammed Takase, mohammed.takase@ucc.edu.gh | ${ }^{1}$ Department of Environmental Science, School of Biological Sciences, University of Cape Coast, Cape Coast, Ghana.

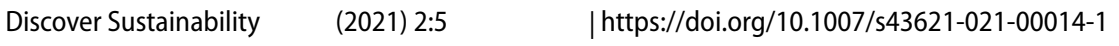


tested as heterogeneous catalyst and have exhibited very good transesterification activity [20]. However, high reaction temperature $\left(200-588^{\circ} \mathrm{C}\right)$ is required for producing their biodiesels. In some instances, supporting these transitional metals with acid or base compounds which has well distributed pores have proven suitable for improving the catalytic activity [21].

Studies have shown that Molybdenum compounds supported with Potassium Carbonate $\left(\mathrm{K}_{2} \mathrm{CO}_{3}\right)$ can be very good heterogeneous catalyst for transesterification of vegetable oil to biodiesel [22, 23]. This is because most molybdenum compounds have low solubility in water. However, when molybdenum bearing minerals get in contact with oxygen and water, the resulting molybdate ion $\mathrm{MoO}_{4}^{2-}$ is quite soluble.

Industrially, molybdenum compounds (about $14 \%$ of world production of the element) are used in high-pressure and high-temperature applications [15]. In this study sodium molybdate $\left(\mathrm{Na}_{2} \mathrm{MoO}_{4}\right)$ has been synthesized and investigated as a heterogeneous catalyst for producing biodiesel from Camelina sativa seed oil.

Camelina sativa is a broadleaf oilseed flowering plant of the Brassicaceae family and grows optimally in temperate climates. It originated from Germany in around 600 B.C. and later spread to Central Europe. From the beginning of 20th century up to the 1930s, Camelina sativa was grown sporadically in France, Belgium, Africa and Holland. In Ghana, it is indigenous to the Volta Region. Camelina sativa grows very well in less rainfall and less fertile lands. It also thrives in cool, arid climates and is adapted to the northern regions of North America and Asia. The yield of Camelina sativa is somewhere from 336 to $2240 \mathrm{~kg}$ of seeds per hectare at maturity.

In Camelina sativa industrial oil production in Ghana located at Ho, Volta Region, the oil is considered a by-product and has not been exploited for various uses. This provides practical foundation for developing the Camelina sativa seed oil to biodiesel. This study is therefore, aimed at producing biodiesel from Camelina sativa oil using modified sodium molybdate as an efficient high yielding heterogeneous catalyst. Even though catalysts based on molybdenum compounds have shown very efficiency in the epoxidation of cyclic olefins [15], the catalyst that has been synthesized in this study has not been investigated for transesterification of oils to biodiesel. It is expected that the outcome of this study will go a long way to enhance the cultivation of Camelina sativa plant in Ghana and also sell out the oil which is currently treated as a by-product. The catalyst will also contribute to reducing cost of biodiesel production since catalyst is one of the main sources of biodiesel cost.

\section{Experimental}

\subsection{Materials}

The oxide of molybdenum $\left(\mathrm{MoO}_{3}\right)$ and sodium molybdate dihydrate $\left(\mathrm{Na}_{2} \mathrm{MoO}_{4} 2 \mathrm{H}_{2} \mathrm{O}\right)$ were bought from Ryte Aid Pharmacy (Ho, Ghana). Unless specified otherwise, all other reagents were used as received without further purification. The Camelina sativa seeds were obtained from Ryte Aid Chemicals (Ghana).

\subsection{Extraction of Camelina sativa oil}

The seeds of Camelina sativa were subjected to drying at $110^{\circ} \mathrm{C}$ for a period of $9 \mathrm{~h}$ in oven for the purpose of removing the extra moisture. The dried seeds were then grounded and weighed. The process of extraction was done by means of soxhlet extractor using petroleum ether $\left(60-90^{\circ} \mathrm{C}\right)$ for a period of $8 \mathrm{~h} .6 \mathrm{~L}$ of petroleum ether for every kilogram of Camelina sativa seeds was applied. The extracted oil was recovered using rotary evaporator and the amount determined using Li et al. [24] recommended procedure (Fig. 1).

Fig. 1 Indigenous Ghanaian Camelina sativa (a) plant and (b) seeds

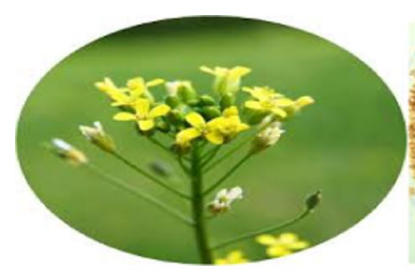

(a)

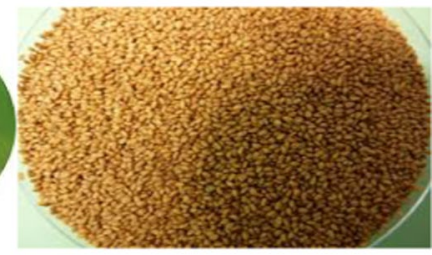

(b) 


\subsection{Catalysts synthesis}

$\mathrm{MoO}_{3}(0.1450 \mathrm{~mol})$ was first dried at $500^{\circ} \mathrm{C}$ for $3 \mathrm{~h}$ and then dissolved in $11 \mathrm{~mol} \mathrm{~L}{ }^{1} \mathrm{NaOH}$. Methanol $(70 \mathrm{~mL})$ was added to the mixture and the recovery of $\mathrm{Na}_{2} \mathrm{MoO}_{4} 2 \mathrm{H}_{2} \mathrm{O}$ was done through filtration, then washed with methanol and acetone and finally dried for $3 \mathrm{~h}$ at $120^{\circ} \mathrm{C}$. For comparative purposes, a commercial sample of $\mathrm{Na}_{2} \mathrm{MoO}_{4} 2 \mathrm{H}_{2} \mathrm{O}$ (Synth) as reference was obtained and used after drying at $120^{\circ} \mathrm{C}$ for $3 \mathrm{~h}$.

\subsection{Catalyst characterization}

The characterizations of the basic strength of the catalysts were done using Hammett indicator procedure [25, 26]. Typically, this was done by keeping $300 \mathrm{mg}$ of the sample in a $1 \mathrm{ml}$ solution of Hammett indicators, then followed by dilution using a $10 \mathrm{ml}$ of methanol. The reaction proceeded for about $2.5 \mathrm{~h}$ to allowed equilibrium to be reached. The basic strength was therefore defined as being stronger than the weakest indicator which exhibits a color change but weaker than the strongest indicator that produced no color change. The Hammett indicators that were used included; bromothymol blue $\left(H \_7.2\right)$, phenolphthalein $\left(H \_9.8\right), 2$,4-dinitroaniline $\left(H \_15\right)$ and 4-nitroaniline $\left(H \_18.4\right)$. Hammett indicator benzene carboxylic acid $(0.02 \mathrm{~mol} / \mathrm{L}$ anhydrous ethanol solution) titration method was used in the determination of the basicity of the solid catalyst.

The shapes and surface characteristics of the samples were examined on a field emission scanning electron microscope (S-4800, HITACHI Corp., Tokyo, Japan) at the accelerating voltage of 20-kV.

Thermogravimetric analysis (TGA) was carried out on a Netzsch instrument (STA 449C, Netzsch, Seligenstadt, Germany). The heating programme ranged from room temperature to $800^{\circ} \mathrm{C}$ with the rate of heating being $10^{\circ} \mathrm{C} / \mathrm{min}$ under a nitrogen atmosphere. The measurement was taken for 5-10 mg samples.

The nitrogen adsorption and desorption isotherms were measured at $-196^{\circ} \mathrm{C}$ using NDVA2000e analytical system (Quntachrome Corporation, USA). The surface areas were calculated by means of Brunauer-Emmett-Teller (BET) method. The size of the pore and its distribution as well as the volumes of the pores were determined using Barrett-Joyner-Halenda (BJH) method.

Intermediate compounds of the catalyst were analyzed by X-ray diffractometer using a reflection scan with nickelfiltered Cu Ka radiation (D8, Bruker-AXS, Germany) diffractometer. The XRD measurements were done at $2 \theta^{\circ}$ values of between 20 and $80^{\circ}$.

The Fourier transform infrared (FT-IR) of the catalyst samples was done using potassium bromide (KBr) powder method on a FTIR spectrometer (AVATAR 360, Nicolet, Madison, USA) with a resolution of 2/cm in the 4000-500/cm range. 32 scans were carried out.

\subsection{Transesterification experiments}

Transesterification reaction of triglycerides to fatty acid methyl esters was done using $30 \mathrm{~g}$ of the oil with varied molar ratio $(9: 1-17: 1)$ of methanol to oil and catalyst in various amounts $(2-10 \%)$, with reference to the weight of the oil. The mixture was refluxed in a $250 \mathrm{ml}$ three-neck reaction flask equipped with a condenser and magnetic stirrer (600 rpm) at different times $(1-3 \mathrm{~h})$ and temperatures $\left(40-70^{\circ} \mathrm{C}\right)$. After the reaction, the mixture was washed with $n$-hexane to remove any absorbed fatty acid methyl esters (FAMEs) out of the solid catalyst. The mixture was subsequently centrifuged at $5000 \mathrm{rpm}$ for $10 \mathrm{~min}$ to ensure separation of the solid catalyst from the liquid layer containing the biodiesel and $n$-hexane. The decanted liquid phase was then transferred to a rotary vacuum evaporator to remove the $n$-hexane and any other by-products from the biodiesel. Each biodiesel sample was then kept in separatory funnel and allowed to stand for $24 \mathrm{~h}$ before washing with water three times. Drying and analyses of the biodiesel then followed.

The biodiesel samples were analysed using 7890A gas chromatograph (Agilent Technology Inc. USA), equipped with a flame-ionization detector (FID) and a HP-5 capillary column $(30 \mathrm{~m} \times 0.32 \mathrm{~mm} \times 0.25 \mu \mathrm{m})$. Helium was used as the carrier gas. The oven temperature ramp program was ran using Li et al. [27] method with little modification (typically the oven temperature was held at $160^{\circ} \mathrm{C}$ for $1 \mathrm{~min}$, then increased to $210^{\circ} \mathrm{C}$ at $20^{\circ} \mathrm{C} / \mathrm{min}$ for $2 \mathrm{~min}$ then further increased from $210^{\circ} \mathrm{C}$ to $213^{\circ} \mathrm{C}$ at $0.3^{\circ} \mathrm{C} / \mathrm{min}$ for $3 \mathrm{~min}$, and finally increased to $250^{\circ} \mathrm{C}$ at $30^{\circ} \mathrm{C} / \mathrm{min}$ for $1 \mathrm{~min}$ ). Hydrogen gas's flow rate was $40 \mathrm{~mL} / \mathrm{min}$ and that of air was $400 \mathrm{~mL} / \mathrm{min}$. Temperature of the injector and detector were set at $250^{\circ} \mathrm{C}$. The injection was done in split mode with a split ratio of 30:1. Analysis of the biodiesel samples was done by dissolving $1 \mathrm{~mL}$ of the biodiesel with $5 \mathrm{~mL}$ of petroleum ether $\left(30-60^{\circ} \mathrm{C}\right)$ in the presence of tetradecane as the internal standard and $0.5 \mu \mathrm{L}$ of the solution injected into GC. The yield of each biodiesel sample was calculated from the content of esters 
Table 1 Physico-chemical properties of Camelina sativa oil

\begin{tabular}{llc}
\hline Property & Method & Camelina sativa oil \\
\hline Fatty acid composition $^{\mathrm{a}}(\%)$ & AOAC (2005) & 16.05 \\
(i) $(\mathrm{C} 16: 0)$ Palmitic acid & $963.22,969.33$ & 3.34 \\
(ii) $(\mathrm{C} 18: 0)$ Stearic acid & & 8.79 \\
(iii) $(\mathrm{C} 18: 1)$ Oleic acid & 64.56 \\
(iv) $(\mathrm{C} 18: 2)$ Linoleic acid & & 6.23 \\
(v) $(\mathrm{C} 20: 0)$ Arachidic acid & ASTMD4052-96 & 918.4 \\
Density $\left(\mathrm{kg} / \mathrm{m}^{3}\right)$ at $15^{\circ} \mathrm{C}$ & & 192.42 \\
Saponification no & ASTMD 445-06 & 36.3 \\
Kinematic viscosity at $40{ }^{\circ} \mathrm{C}, \mathrm{mm}^{2} / \mathrm{s}$ & & 888.7 \\
Average molecular weight $(\mathrm{g})$ & AOAC 984.20-90 & 0.096 \\
Water content $(\%) \mathrm{w} / \mathrm{w}$ & AOAC 940.28 & 0.58 \\
\hline
\end{tabular}

${ }^{a}$ Other fatty acids (palmitoleic, 10-nonadecenoic, myristic, nonadecanoic, heneicosanoic, and heptadecanoic acid) were present in amounts of $<1 \%$
Fig. 2 SEM photograph of sodium molybdenum oxide $\left(\mathrm{Na}_{2} \mathrm{MoO}_{4} 2 \mathrm{H}_{2} \mathrm{O}\right)$

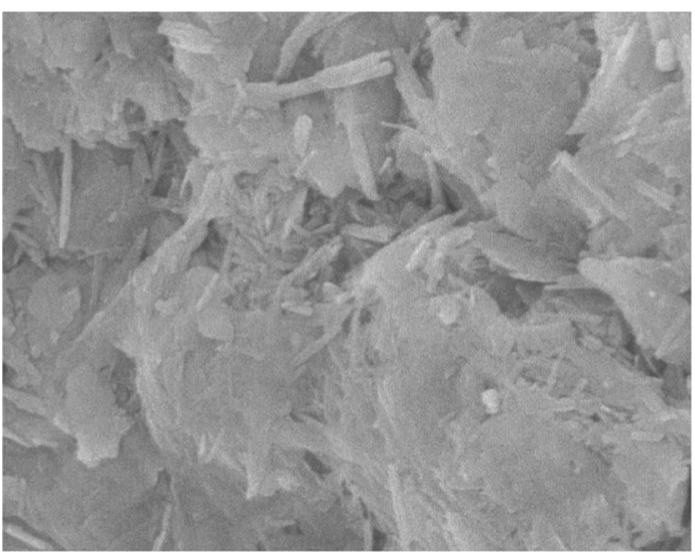

using Qiu et al. [28] method. All data in this study are presented as mean (values) of triplicate of experimental and GC determinations with standard deviations.

\section{Results and discussion}

\subsection{Extraction of oil}

Having extracted the oil from the seeds, the amount was calculated using Li et al. [24] method. The content of oil in the seeds (41\%) was however, comparable to those of other oils and this indicated that the seeds contain relatively high amount of oil [29,30]. High amount of free fatty acid and water content in oils leads to soap formation and this can lower the yield of biodiesel [31]. The free fatty acids and water content in the oil in this case was less than one thus, closer to other oil(s) [32]. Table 1 shows the composition of oil in the seeds.

\subsection{Catalyst characterization}

SEM photographs of sodium molybdate dihydrate $\left(\mathrm{Na}_{2} \mathrm{MoO}_{4} 2 \mathrm{H}_{2} \mathrm{O}\right)$ is shown in Fig. 2. The SEM image of sodium molybdate dihydrate $\left(\mathrm{Na}_{2} \mathrm{MoO}_{4} 2 \mathrm{H}_{2} \mathrm{O}\right)$ sample shows crystallites of $1 \mu \mathrm{m}$ size. The crystallites shape of sodium molybdate dihydrate $\left(\mathrm{Na}_{2} \mathrm{MoO}_{4} 2 \mathrm{H}_{2} \mathrm{O}\right)$ image suggest that there is a good dispersion of $\mathrm{NaOH}$ onto Molybdenum oxide $\left(\mathrm{MoO}_{3}\right)$.

The BET surface areas of sodium molybdate dihydrate $\left(\mathrm{Na}_{2} \mathrm{MoO}_{4} 2 \mathrm{H}_{2} \mathrm{O}\right)$ was $5.2 \mathrm{~m}^{2} \mathrm{~g}^{-1}$ while the pore volume of sodium molybdate dihydrate $\left(\mathrm{Na}_{2} \mathrm{MoO}_{4} 2 \mathrm{H}_{2} \mathrm{O}\right)$ was $0.01 \mathrm{~cm}^{3} \mathrm{~g}^{-1}$. From the $\mathrm{BET}$ data, the sodium compounds on sodium molybdate 
Fig. 3 UV spectra of sodium molybdate dihydrate $\left(\mathrm{Na}_{2} \mathrm{MoO}_{4} 2 \mathrm{H}_{2} \mathrm{O}\right)$

Fig. 4 XRD of $A$ (raw) and C [calcined sodium molybdate dihydrate $\left.\left(\mathrm{Na}_{2} \mathrm{MoO}_{4} 2 \mathrm{H}_{2} \mathrm{O}\right)\right]$

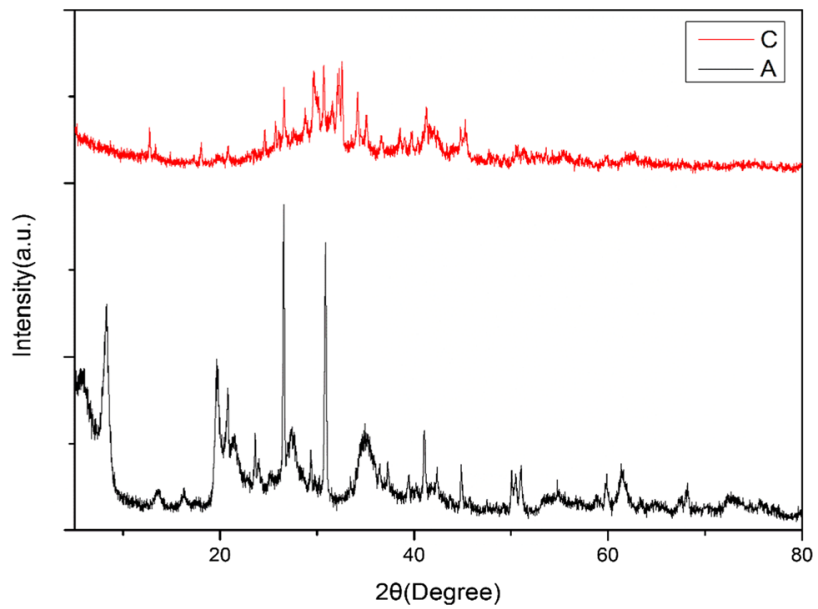

dihydrate $\left(\mathrm{Na}_{2} \mathrm{MoO}_{4} 2 \mathrm{H}_{2} \mathrm{O}\right)$ could generate the catalytic activity for the transesterification reaction. The low pore volume value of the catalyst $\left(\mathrm{cm}^{3} \mathrm{~g}^{-1}\right)$ indicates that the triglyceride molecules can easily penetrate through the pores of the catalyst as indicated by Granadose et al. [33]. This pre-supposes that most of the active sites of the catalyst would be utilized during the transesterification.

The UV-vis spectrum of sodium molybdate dihydrate $\left(\mathrm{Na}_{2} \mathrm{MoO}_{4} 2 \mathrm{H}_{2} \mathrm{O}\right)$ shows a broad band between 400 and $700 \mathrm{~nm}$ which is attributed to $\pi=\pi$ charge transfer transitions in the $\mathrm{C}=\mathrm{O}$ group of $\mathrm{OH}$. This result indicates that the absorbed $\mathrm{NaOH}$ onto Molybdenum oxide $\left(\mathrm{MoO}_{3}\right)$ did fully decompose at $600^{\circ} \mathrm{C}$ (Fig. 3).

Figure 4 shows the XRD patterns of pure $A(r a w)$ and $\mathrm{C}$ [sodium molybdate dihydrate $\left(\mathrm{Na}_{2} \mathrm{MoO}_{4} 2 \mathrm{H}_{2} \mathrm{O}\right)$ ]. There were peaks at $2 \theta=8.4^{\circ}, 20.9^{\circ}, 28.1^{\circ}$ and $31.9^{\circ}$. Upon modifying the sodium molybdate dihydrate $\left(\mathrm{Na}_{2} \mathrm{MoO}_{4} 2 \mathrm{H}_{2} \mathrm{O}\right)$ typical $\mathrm{Na}_{2} \mathrm{MoO}_{4} 2 \mathrm{H}_{2} \mathrm{O}$ peaks appear at $2 \theta=29.1^{\circ}, 31.2^{\circ}, 36.6^{\circ}$ and $45.4^{\circ}$. New phases associated with $\mathrm{Na}_{2} \mathrm{O}$ also appeared at $11.1^{\circ}, 32.3^{\circ}$ and $48.4^{\circ}$.

FT-IR spectra of the sodium molybdate dihydrate $\left(\mathrm{Na}_{2} \mathrm{MoO}_{4} 2 \mathrm{H}_{2} \mathrm{O}\right)$ is shown in Fig. 5 . In the spectrum of the sodium molybdate dihydrate $\left(\mathrm{Na}_{2} \mathrm{MoO}_{4} 2 \mathrm{H}_{2} \mathrm{O}\right), 2$ strong bands at 3428 and $1028 \mathrm{~cm}^{-1}$ can be attributed to the symmetric and asymmetric stretching vibrations of $\mathrm{Na}_{2}=\mathrm{O}$ bond of $\mathrm{Na}_{2} \mathrm{MoO}_{4} 2 \mathrm{H}_{2} \mathrm{O}$. The results confirm the XRD data in Fig. 4.

\subsection{Optimization of transesterification reaction parameters}

\subsubsection{Effect of methanol to oil molar ratio}

Efficiency of triglyceride conversion is strictly dependent on methanol amount used for the transesterification reaction. The molar ratio of methanol to vegetable oil is very important parameter which affect the conversion of triglycerides to 
Fig. 5 FTIR of sodium molybdate dihydrate $\left(\mathrm{Na}_{2} \mathrm{MoO}_{4} 2 \mathrm{H}_{2} \mathrm{O}\right)$

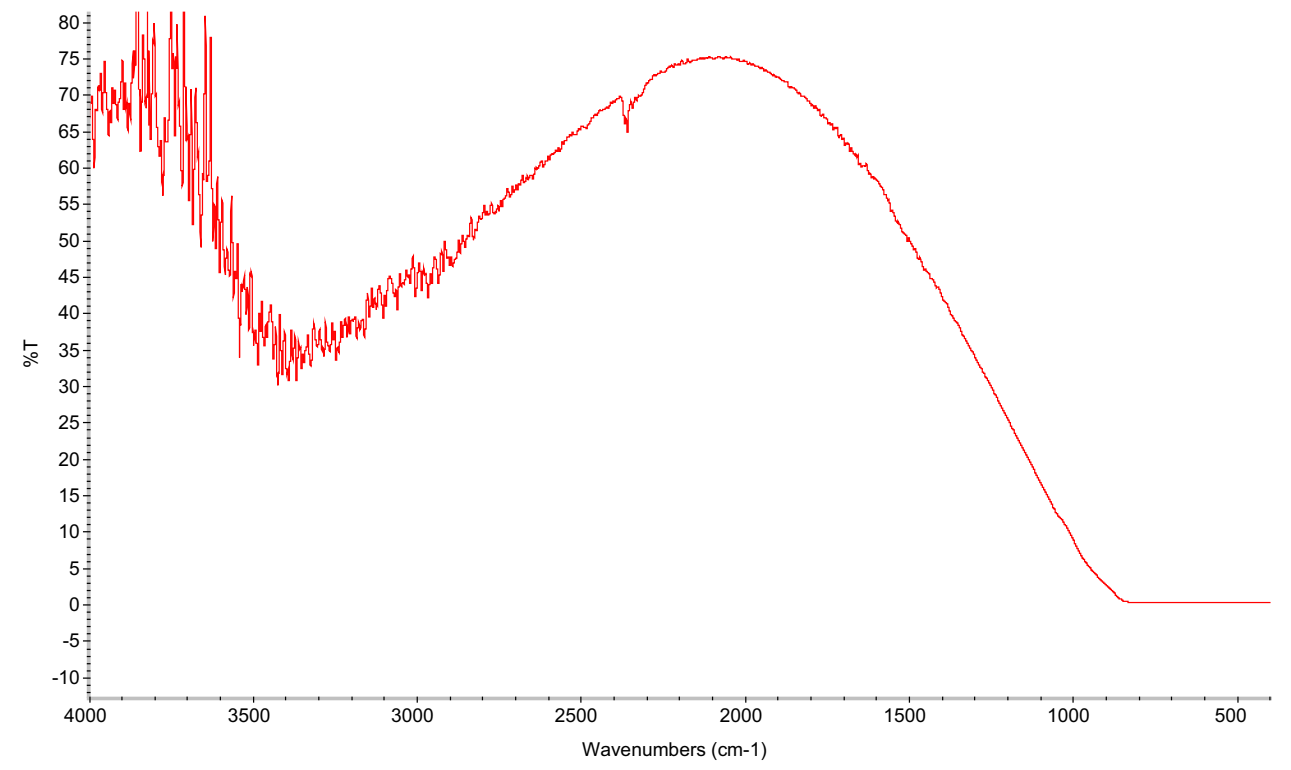

methyl esters [34, 35]. The stoichiometric molar ratio of methanol to Camelina sativa oil is 3:1. However, excess methanol (typically methanol/oil > 6) can be used to increase the yield of methyl esters and facilitate the separation of glycerine [30]. To investigate the effects of methanol to oil ratio for the $\mathrm{Na}_{2} \mathrm{MoO}_{4} 2 \mathrm{H}_{2} \mathrm{O}$ catalyst, the transesterification experiment was conducted by systematically changing the molar ratio of methanol to Camelina sativa oil, i.e., from 9:1 to 19:1 whilst keeping the reaction temperature, catalyst amount and reaction time constant at $60^{\circ} \mathrm{C}, 6 \%$ and $2 \mathrm{~h}$, respectively (Fig. 6). The yield increased as the methanol to oil molar ratio was increased (from 9:1 to 17:1). The results suggest that altering the methanol/oil molar ratio in the 9:1 to 17:1 range did affect the methyl esters yield. The highest methyl ester yield of $90.3 \%$ was reached at the molar methanol/oil ratio of 17:1. The reaction at methanol to oil molar ratio of 9:1 took a longer time to obtain substantial yield indicating that at low molar ratio, the reaction is slow. These data, reported in terms of the standard error of mean according to Origin 8.1, confirmed that methanol/oil ratios that are $>6: 1$ can increase the yield of methyl ester substantially. Comparatively, methanol to oil molar ratio of 19:1 also provided relatively higher yield as 17:1, but this ratio should be avoided for the purpose of cost minimization. To ensure the optimum biodiesel yield, methanol to oil molar ratio of 17:1 in this case was selected.

\subsubsection{Effect of catalyst amount}

In order to examine the influence of catalyst amount on the conversion efficiency of triglyceride to methyl esters, series of reactions were performed by varying the amount of catalyst. Since catalyst accelerates transesterification reactions [30], it will be important to determine the influence of this variable in the conversion of triglyceride to esters. Earlier studies on Cynara cardunculus $L$. indicates that the conversion of oil to its methyl ester by transesterification without catalyst $(0 \% \mathrm{NaOH})[36]$ was impossible. In this study, the effects of catalyst amount on methyl ester yield was investigated

Fig. 6 Effects of methanol: oil ratio (reaction temperature 60 ${ }^{\circ} \mathrm{C}$, catalyst amount $6 \%$ and reaction time of $2 \mathrm{~h}$ )

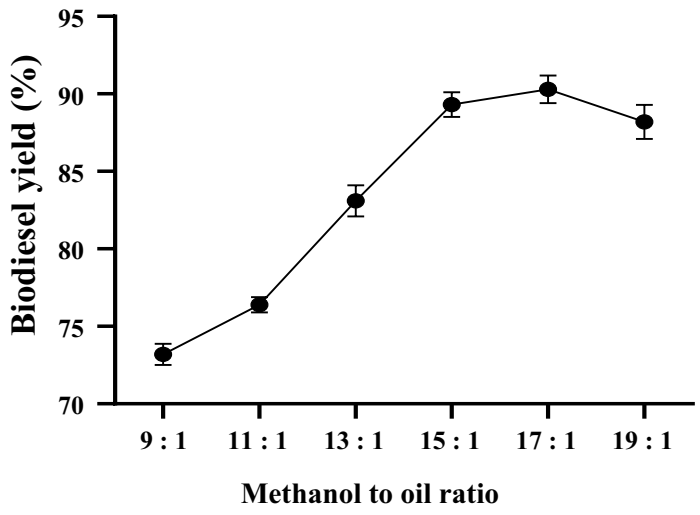



amount (methanol to oil molar ratio of $17: 1$, reaction temperature of $60^{\circ} \mathrm{C}$ and reaction time of $2 \mathrm{~h}$ )
Fig. 7 Effect of catalyst

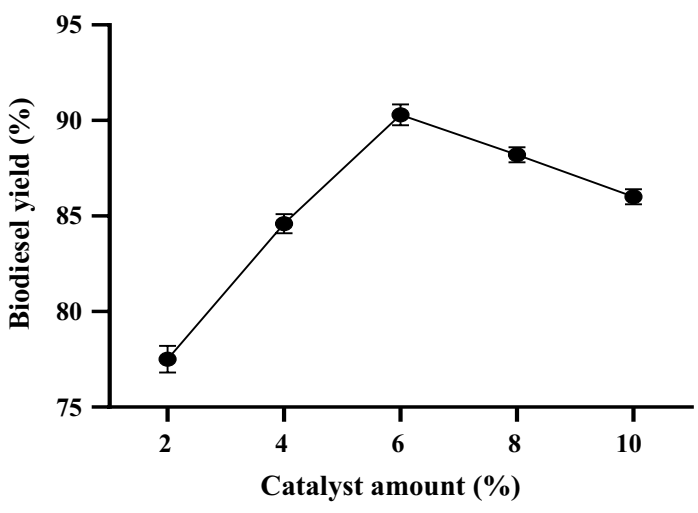

Fig. 8 Effect of reaction temperature (reaction time $2 \mathrm{~h}$, methanol to oil molar ratio of $17: 1$ and catalyst amount of $6 \%$ )

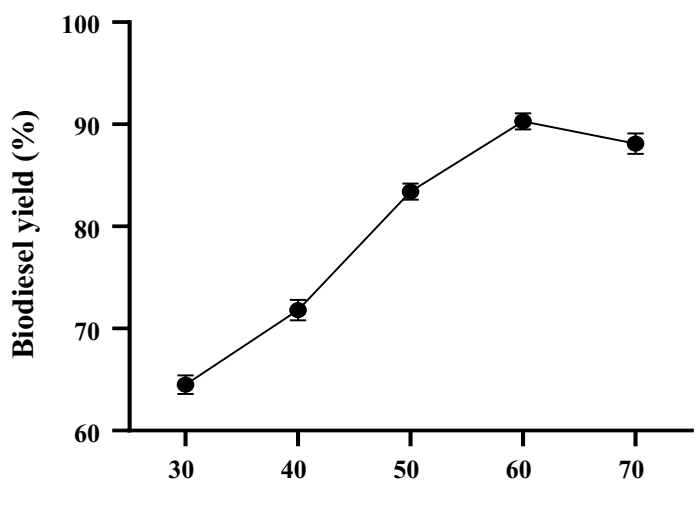

Reaction temperature $\left({ }^{\circ} \mathrm{C}\right)$

at the mass ratio of $\mathrm{Na}_{2} \mathrm{MoO}_{4} 2 \mathrm{H}_{2} \mathrm{O}$ to Camelina sativa seed oil at a varied range of 2 to $10 \%$ using 17:1 methanol to oil molar ratio at reaction time of $2 \mathrm{~h}$ and reaction temperature of $60^{\circ} \mathrm{C}$ (Fig. 7). The percentages of the $\mathrm{Na}_{2} \mathrm{MoO}_{4} 2 \mathrm{H}_{2} \mathrm{O}$ were weight fractions of the oil used for the reaction. Figure 7 indicate that, increase in catalyst amount (from 2 to $6 \%$ ) leads to increase in methyl ester yield till a plateau value (90.3) was reached. This findings agree with other studies [31, 36]. At the lowest catalyst amount (2\%) the reaction was slow, indicating insufficient amount of the catalyst to catalyze the process to completion. At $6 \%$ of $\mathrm{Na}_{2} \mathrm{MoO}_{4} 2 \mathrm{H}_{2} \mathrm{O}, 90.3 \%$ yield of methyl esters was generated. This is consistent with earlier discussion on screening of catalyst on the effect of basicity on biodiesel yield. Similar conclusions were also reached in the 2011 study of Qiu et al. [28] when $\mathrm{Na}_{2} \mathrm{MoO}_{4}$ salts were loaded on $\mathrm{ZrO}_{2}$ to increase the basicity of $\mathrm{ZrO}_{2}$ surfaces. It is however, noted that when the catalyst amount was increased further from 6 to $8 \%$, the yield however, dropped slightly from that of $6 \%[31,36]$, which was due to the addition of a higher amount of the catalyst, causing slight soap formation thereby inhibiting the reaction process which consequently increased the viscosity of the reactants [31]. Considering economic reasons, $6 \%$ catalyst was proposed to be used for further reactions.

\subsubsection{Effect of reaction temperature}

Transesterification of Camelina sativa oil was analyzed at temperatures of $40-70^{\circ} \mathrm{C}$ and the obtained results are shown in Fig. 8. Studies indicate that reaction temperature has an important effect on base-catalyzed transesterification [31, 36]. The effect of reaction temperature on the transesterification of crude Camelina sativa seed oil was investigated at different temperatures $\left(40,50,60,65\right.$ and $\left.70^{\circ} \mathrm{C}\right)$ with methanol to oil molar ratio of $17: 1$ and catalyst amount of $6 \%$ in $2 \mathrm{~h}$ (Fig. 8). As shown in Fig. 8, the reaction rate was slow at low temperatures. The reaction however, proceeded till a yield of $90.3 \%$ was reached. Evidently, the methyl esters yield increased with increasing reaction temperature till maximum at $60^{\circ} \mathrm{C}(90.3 \%)$. The maximum temperature studied i.e., $60^{\circ} \mathrm{C}$ however, coincides with the boiling point of methanol. Further increase in temperature does have a little impact at the yield of the biodiesel while the foremost advantage of higher temperatures takes less reaction time. Henceforth, the optimum reaction temperature for the transesterification reaction was $60^{\circ} \mathrm{C}$. 
Fig. 9 Effect of reaction time (methanol to oil molar ratio of $15: 1$, reaction temperature of $60^{\circ} \mathrm{C}$ and catalyst amount of $6 \%$ )

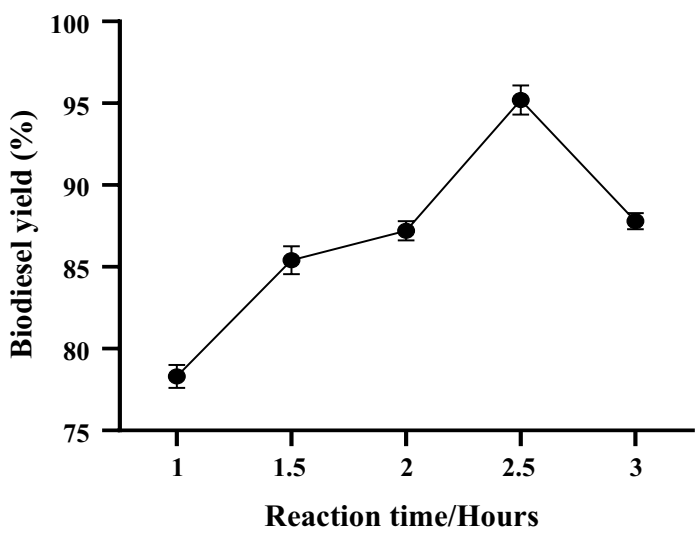

Fig. 10 Catalyst regeneration (methanol to oil molar ratio of $15: 1$, reaction temperature of $60^{\circ} \mathrm{C}$, catalyst amount of $6 \%$ and reaction time of $2.5 \mathrm{~h}$ )

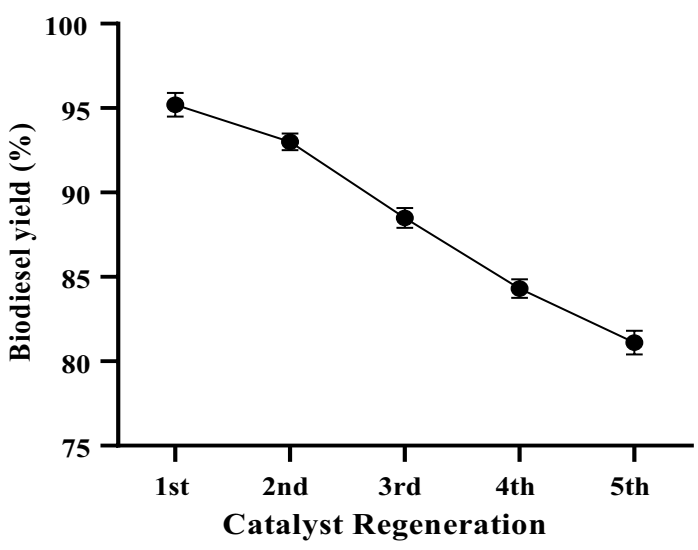

\subsubsection{Effect of reaction time}

Duration of reaction also have significant influence on transesterification efficiency as triglycerides in oil starts degrading after long time. The reaction time was varied in the range of $1-3 \mathrm{~h}$. Figure 9 revealed that the transesterification reaction was strongly dependent on reaction time. At the beginning $(1 \mathrm{~h})$, the reaction was slow due to the mixing and the dispersion of methanol into oil. The reaction however, proceeded with increase in yield till the yield (95.2\%) was reached in $2.5 \mathrm{~h}$. After that $(2.5 \mathrm{~h})$, further increase in the time led to a reduction in the yield possibly due to reversible reaction [37]. On the basis of the optimum yield (95.2\%), $2.5 \mathrm{~h}$ was selected as optimum reaction time.

\subsection{Catalyst regeneration}

A stable catalyst should have resistance toward impurities. A fresh reaction mixture of $\mathrm{Na}_{2} \mathrm{MoO}_{4} 2 \mathrm{H}_{2} \mathrm{O}$, methanol and Camelina sativa seed oil were used at each cycle of the stability tests. The typical results of methyl ester yield of the number of cycles are shown in Fig. 10. For all the five runs, the rate of reaction was very high at the end of the $2.5 \mathrm{~h}$ reaction period (with the methyl esters yield exceeding $80 \%$ ). The range of reduction of the yield of methyl ester was from $95.2 \%$ (fresh use), to $81.1 \%$ (fifth reuse) (Fig. 10). In all, about $14.1 \%$ of total esters was reduced at the end of the fifth run, suggesting that the catalyst particles were stable. The reduction in the yield after each cycle of reuse was possibly due to leaching of $\mathrm{Na}$ [38-40]. Figure 11 show GC-MS spectrum of the biodiesel at the optimum reaction condition.

\subsection{Comparison of Camelina sativa biodiesel properties to international standards}

The Camelina sativa biodiesel produced at the optimum reaction conditions were tested for their quality and the standards compared with those of European Union-EN 14214 (2008) and American ASTM D 6751 (07b) (Table 2). The properties including cetane number, kinematic viscosity, flash point, acid value, copper strip corrosion and water content among others were comparable to the international standards. The cloud point of biodiesel reflecting its cold weather 
Fig. 11 GC-MS of the biodiesel at the optimum reaction conditions
Table 2 Comparison of properties of the Camelina sativa biodiesel and the standards of Europe and the United States

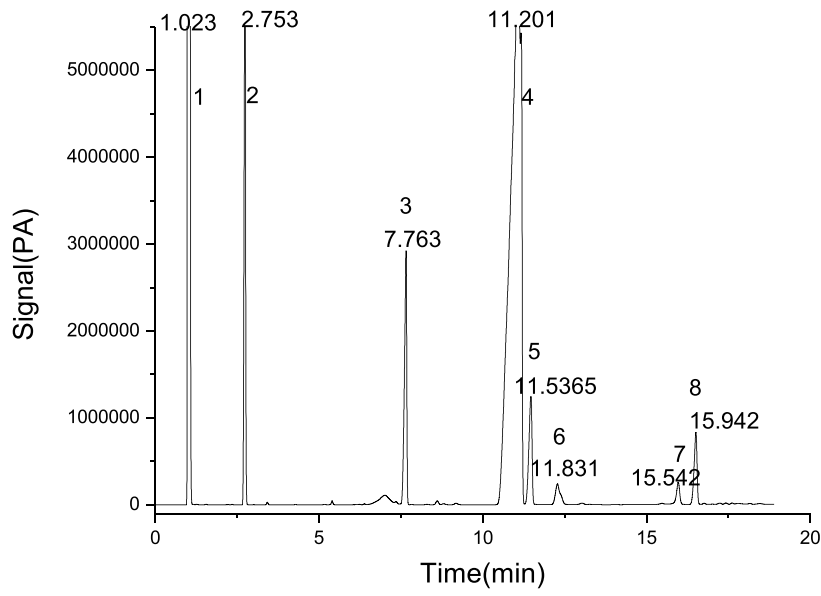

\begin{tabular}{lllll}
\hline Item & Method & $\begin{array}{l}\text { C. sativa bio- } \\
\text { diesel [33] }\end{array}$ & $\begin{array}{l}\text { USA ASTMD } \\
6751-03[41]\end{array}$ & $\begin{array}{l}\text { EUROPE } \\
\text { EN 14214 } \\
{[33]}\end{array}$ \\
\hline Cetane number & & & $\geq 47$ & $\geq 51$ \\
Density $\left(20^{\circ} \mathrm{C}\right)$ & ASTM D6890 & 52 & - & $860-900$ \\
Flash point $\left({ }^{\circ} \mathrm{C}\right)$ & SH/T0248 & 875 & $\geq 93$ & $\geq 120$ \\
Cloud point $\left({ }^{\circ} \mathrm{C}\right)$ & ASTM D93 & 148 & - & - \\
Sulfur content $(\%, \mathrm{w} / \mathrm{w})$ & GB/T510 & -2 & $\leq 0.05$ & 0.02 \\
Acid value $(\mathrm{KOH} \mathrm{mg} / \mathrm{kg})$ & ASTM D4294 & 0.002 & $\leq 0.5$ & $\leq 0.5$ \\
Water $(\mathrm{mg} / \mathrm{kg})$ & ASTM D664-01 & 0.41 & $\leq 0.05$ & $\leq 0.05$ \\
Total glycerine $(\%, \mathrm{w} / \mathrm{w})$ & ASTM D6304 & 0.05 & 0.24 & $\leq 0.25$ \\
Ash content $(\%, \mathrm{w} / \mathrm{w})$ & EN 14105 & 0.13 & $\leq 0.02$ & $\leq 0.02$ \\
Kinematic viscosity $\left(\mathrm{mm} / \mathrm{s} ; 40{ }^{\circ} \mathrm{C}\right)$ & ASTM D445 & 3.9 & $1.9-6.0$ & $3.5-5.0$ \\
\hline
\end{tabular}

performance indicate that the methyl esters of Camelina sativa seed oil can be used as fuel in relatively cold-weather conditions without much problem [33]. The flash point of the biodiesel $\left(148^{\circ} \mathrm{C}\right)$ was however, higher than that of diesel and when blended with diesel $\left(67.5^{\circ} \mathrm{C}\right)$, could be reduced [41]. In all, the properties of the methyl esters were comparable to international standards.

\section{Conclusions}

In this study sodium molybdate $\left(\mathrm{Na}_{2} \mathrm{MoO}_{4} 2 \mathrm{H}_{2} \mathrm{O}\right)$ has been prepared and investigated as efficient heterogeneous solid catalyst for transesterificating Camelina sativa seed oil to biodiesel. The transesterification reaction was very efficient, with the optimum yield higher than $95 \%$ at methanol to oil molar ratio of $17: 1$, catalyst amount of $6 \%$, reaction temperature of $60^{\circ} \mathrm{C}$ and reaction time of $2.5 \mathrm{~h}$. The catalyst was characterised using SEM, TGA, UV, XRD and FTIR. The catalyst indicated sustained reusability of 5 times with yield of $81.1 \%$ at the 5 th reuse. The catalyst was easily recovered and after being washed showed capacity of recyclability for another catalytic reaction of five cycles with similar activity. The properties of the biodiesel were comparable to international standards.

Acknowledgements The research was supported by MICMOD Foundation, Ghana. We also thank Dr. Michael Miyittah for modifying or revising the English language of the manuscript.

Availability of data and materials All data associated with this manuscript is embedded in the text.

Competing interests The authors declare that there are no conflicts of interest. 
Open Access This article is licensed under a Creative Commons Attribution 4.0 International License, which permits use, sharing, adaptation, distribution and reproduction in any medium or format, as long as you give appropriate credit to the original author(s) and the source, provide a link to the Creative Commons licence, and indicate if changes were made. The images or other third party material in this article are included in the article's Creative Commons licence, unless indicated otherwise in a credit line to the material. If material is not included in the article's Creative Commons licence and your intended use is not permitted by statutory regulation or exceeds the permitted use, you will need to obtain permission directly from the copyright holder. To view a copy of this licence, visit http://creativecommons.org/licenses/by/4.0/.

\section{References}

1. Abdoli MA, Mohamadi F, Ghobadian B, Fayyazi E. Effective parameters on biodiesel production from feather fat oil as a cost-effective feedstock. Int J Environ Res. 2014;8:139-48.

2. Su CH. Recoverable and reusable hydrochloric acid used as a homogeneous catalyst for biodiesel production. Appl Energy. 2013;104:503-9.

3. Vyas AP, Verma JL, Subrahmanyam N. A review on FAME production processes. Fuel. 2010;89:1-9.

4. Yusoff MFM, Xu XB, Guo Z. Comparison of fatty acid methyl and ethyl esters as biodiesel base stock: a review on processing and production requirements. J Am Oil Chem Soc. 2014;91:525e31.

5. Zabeti M, Daud WMAW, Aroua MK. Activity of solid catalysts for biodiesel production: a review. Fuel Process Technol. 2009;90:770-7.

6. Zabeti M, Daud WMAW, Aroua MK. Optimization of the activity of $\mathrm{CaO} / \mathrm{Al}_{2} \mathrm{O}_{3}$ catalyst for biodiesel production using response surface methodology. Appl Catal a-General. 2009;366:154e9.

7. Kim M, DiMaggio C, Salley SO, Ng KYS. A new generation of zirconia supported metal oxide catalysts for converting low grade renewable feedstocks to biodiesel. Bioresour Technol. 2012;118:37-42.

8. Di Serio M, Carotenuto G, Cucciolito ME, Lega M, Ruffo F, Tesser R, et al. Shiff base complexes of zinc(II) as catalysts for biodiesel production. J Mol Catal a-Chem. 2012;353:106-10.

9. Chen W, Huang ZL, Liu Y, He QJ. Preparation and characterization of a novel solid base catalyst hydroxyapatite loaded with strontium. Catal Commun. 2008;9:516-21.

10. Abidin SZ, Haigh KF, Saha B. Esterification of free fatty acids in used cooking oil using ion-exchange resins as catalysts: an efficient pretreatment method for biodiesel feedstock. Ind Eng Chem Res. 2012;51:14653-64.

11. Howard JB, Hartmann R. Synthesis and determination of the catalytic role of tungsten bound resins for biodiesel production. Abstr Pap Am Chem Soc. 2011;241.

12. Yan JY, Li AT, Xu Y, Ngo TPN, Phua S, Li Z. Efficient production of biodiesel from waste grease: one-pot esterification and transesterification with tandem lipases. Bioresour Technol. 2012;123:332-7.

13. Carrero A, Vicente G, Rodriguez R, Linares M, del Peso GL. Hierarchical zeolites as catalysts for biodiesel production from nannochloropsis microalga oil. Catal Today. 2011;167:148-53.

14. Liu H, Su L, Liu F, Li C, Solomon UU. Cinder supported $\mathrm{K}_{2} \mathrm{CO}_{3}$ as catalyst for biodiesel production. Appl Catal B Environ. 2011;106:550-8.

15. Shiratori Y, Quang-Tuyen T, Umemura Y, Kitaoka T, Sasaki K. Paper-structured catalyst for the steam reforming of biodiesel fuel. Int $J$ Hydrogen Energy. 2013;38:11278-87.

16. Nasreen S, Liu H, Skala D, Waseem A, Wan L. Preparation of biodiesel from soybean oil using La/Mn oxide catalyst. Fuel Process Technol. 2015;131:290-6.

17. Yan S, Salley SO, Simon Ng KY. Simultaneous transesterification and esterification of unrefined or waste oils over $\mathrm{ZnO}-\mathrm{La}_{2} \mathrm{O}_{3}$ catalysts. Appl Catal A General. 2009;353(2):203-12.

18. Tzompantzi Y, Carrera G, Morales-Mendozaa G, Valverde-Aguilar G, Mantillab A. $\mathrm{ZnO}-\mathrm{Al}_{2} \mathrm{O}_{3}-\mathrm{La}_{2} \mathrm{O}_{3}$ layered double hydroxides as catalysts precursors for the esterification of oleic acid fatty grass at low temperature. Catal Today. 2013;212:164-8.

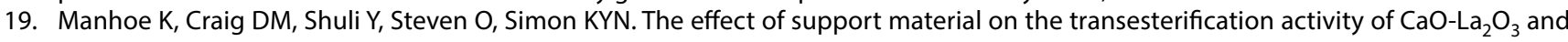
$\mathrm{CaO}-\mathrm{CeO}_{2}$ supported catalysts. Green Chem. 2011;13:334-40.

20. Ouanji F, Khachani M, Boualag M, Kacimi M, Ziyad M. Largescale biodiesel production from Moroccan used frying oil. Int J Hydrogen Energy. 2016;41:21022-9.

21. Ahmad I, Khan MA, Shakirullah M, Ishaq M, Ahmad R, Rehman HU, et al. Study on influence of catalysts on product distribution during liquefaction of Pakistani coal. Energy Convers Manag. 2007;48:2502-7.

22. Liu H, Su LY, Shao Y, Zou LB. Biodiesel production catalyzed by Cinder supported CaO/KF particle catalyst. Fuel. 2012;97:651-7.

23. Chen W-K, Tseng H-H, Wei M-C, Su E-C, Chiu IC. Transesterification of canola oil as biodiesel over Na/Zr-SBA-15 catalysts: effect of zirconium content. Int J Hydrogen Energy. 2014;39:19555-62.

24. Kawashima A, Matsubara K, Honda K. Development of heterogeneous base catalysts for biodiesel production. Biores Technol. 2008;99:3439-43.

25. Yang R, Su M, Li M, Zhang J, Hao X, Zhang H. One-pot process combining transesterification and selective hydrogenation for biodiesel production from starting material of high degree of unsaturation. Biores Technol. 2010;101:5903-9.

26. Yoo SJ, Lee H-S, Veriansyah B, Kim J, Kim J-D, Lee Y-W. Synthesis of biodiesel from rapeseed oil using supercritical methanol with metal oxide catalysts. Biores Technol. 2010;101:8686-9.

27. Li F, Yang L, Zhao T, Zhao J, Zou Y, Zou Y, et al. Optimization of enzymatic pretreatment for $n$-hexane extraction of oil from Silybum marianum seeds using response surface methodology. Food Bioprod Process. 2012;90:87-94.

28. Qiu F, Li Y, Yang D, Li X, Sun P. Heterogeneous solid base nanocatalyst: preparation, characterization and application in biodiesel production. Biores Technol. 2011;102:4150-6.

29. Li Y, Qiu F, Yang D, Li X, Sun P. Preparation, characterization and application of heterogeneous solid base catalyst for biodiesel production from soybean oil. Biomass Bioenerg. 2011;35:2787-95.

30. Meher L, Vidya Sagar D, Naik S. Technical aspects of biodiesel production by transesterification-a review. Renew Sustain Energy Rev. $2006 ; 10: 248-68$. 
31. Meher L, Dharmagadda VS, Naik S. Optimization of alkali-catalyzed transesterification of Pongamia pinnata oil for production of biodiesel. Biores Technol. 2006;97:1392-7.

32. Nakpong P, Wootthikanokkhan S. Roselle (Hibiscus sabdariffa L.) oil as an alternative feedstock for biodiesel production in Thailand. Fuel. 2010;89:1806-11.

33. Atadashi IM, Aroua MK, Aziz AA. Biodiesel separation and purification: a review. Renew Energy. 2011;36:437-43.

34. Liu X, He H, Wang Y, Zhu S, Piao X. Transesterification of soybean oil to biodiesel using CaO as a solid base catalyst. Fuel. 2008;87:216-21.

35. Xie W, Li H. Alumina-supported potassium iodide as a heterogeneous catalyst for biodiesel production from soybean oil. J Mol Catal A Chem. 2006;255:1-9.

36. Encinar JM, González JF, Sabio E, Ramiro MJ. Preparation and properties of biodiesel from Cynaracardunculus L. Oil Indus Eng Chem Res. 1999;38:2927-31.

37. Lin L, Cunshan Z, Vittayapadung S, Xiangqian S, Mingdong D. Opportunities and challenges for biodiesel fuel. Appl Energy. 2011;88:1020-31.

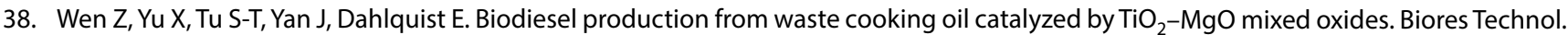
2010;101:9570-6.

39. Boz N, Degirmenbasi N, Kalyon DM. Conversion of biomass to fuel: transesterification of vegetable oil to biodiesel using KF loaded nano$\mathrm{Y}-\mathrm{Al}_{2} \mathrm{O}_{3}$ as catalyst. Appl Catal B. 2009;89:590-6.

40. Soetaredjo FE, Ayucitra A, Ismadji S, Maukar AL. KOH/bentonite catalysts for transesterification of palm oil to biodiesel. Appl Clay Sci. 2011;53:341-6.

41. Ramadhas AS, Muraleedharan C, Jayaraj S. Performance and emission evaluation of a diesel engine fueled with methyl esters of rubber seed oil. Renew Energy. 2005;30:1789-800.

Publisher's Note Springer Nature remains neutral with regard to jurisdictional claims in published maps and institutional affiliations. 